\title{
Narrative research: An alternative approach to study language teaching and learning
}

\author{
Investigación Narrativa: \\ Un enfoque alternativo para estudiar la enseñanza y \\ el aprendizaje de idiomas
}

Jenny Alexandra Mendieta ${ }^{1}$

\section{Abstract}

The use of stories in research help us better understand the world of teaching and learning since teachers and learners, like any other human being, are storytellers who engage in narrative acts to make sense of their and others' knowledge and experiences. Yet, narrative research is a path not widely walked in the Colombian language teaching and learning field. This article is therefore an attempt to review some of the epistemological and methodological underpinnings underlying this approach to qualitative research so as to add to the local knowledge of our ELT community. It discusses the role of the researcher, the different orientations narrative studies can take, and the processes involved in narrative analysis. Some of the challenges narrative researchers face in their work as well as the contributions that this method of inquiry has made to both the educational and the TESOL fields are also considered.

Keywords:

Narratives, narrative research, TESOL, education.

Resumen

El uso de historias en procesos de investigación nos ayuda a entender mejor el mundo de la enseñanza y el aprendizaje dado que nuestros maestros y estudiantes, al igual que cualquier otro ser humano, construyen narraciones a fin dar sentido a sus experiencias. Sin embargo, la investigación narrativa es un camino que no ha sido ampliamente recorrido en el campo de la enseñanza de idiomas en Colombia. Este artículo, por tanto, intenta revisar algunos de los fundamentos epistemológicos y metodológicos que subyacen a este enfoque de investigación cualitativa a fin de contribuir al conocimiento local de nuestra comunidad. Aspectos tales como el papel del investigador, las diferentes orientaciones que los estudios de tipo narrativo pueden tomar y los procesos involucrados en el análisis narrativo serán examinados. Algunos de los retos que los investigadores enfrentan en sus trabajos, así como las contribuciones de este método de investigación tanto al campo de la educación como al campo de la enseñanza de idiomas serán igualmente considerados.

Palabras clave:

Narrativa, investigación narrativa, TESOL, educación.

Artículo recibido el 20 de junio de 2012 y aprobado el 8 de febrero de 2013

1 Universidad de la Sabana, Bogotá, Colombia. Correo electrónico: jennymendieta@yahoo.com 
"Human beings are storying creatures. We make sense of the world and the things that happen to us by constructing narratives to explain and interpret events both to ourselves and to other people." Sikes, P. \& Gale, K. (2006).

As stated by Sikes and Gale (2006), we human beings are storying creatures who construct narratives to explain our doings as well as to interpret our and others' past, present and imagined world experiences. If narratives, or stories as they are commonly referred, are present in our day to day, they must then be filled with social and cultural meaning; the meaning we give to our lives and to all what occurs around us. Hence, as narrative researchers have claimed, stories can definitely help us better understand the world of teaching and learning since teachers and learners, like any other human being, are storytellers who engage in narrative acts to make sense of their and others' knowledge and experiences.

Prior to discussing what narrative research is all about and what it could possibly offer to both the educational and ELT fields, it is important to for me to point out the genesis of this article. As part of a previous research experience (See Mendieta, 2011), I committed myself to the task of exploring the power of teachers' knowledge, beliefs and experiences in the interpretation, implementation and evaluation of curriculum. In the analysis of the qualitative approaches that could inform my inquiry, I became familiar with the work of researchers who had examined narratives as a means to comprehend different life-related experiences, and whose work stemmed from social science areas like sociology, psychology and education.

Their work opened a door towards the world of stories and their potential to language teaching and learning research; a path not widely walked in Colombian ELT field but one I thought was definitely worth going through. As a result of this first encounter with narrative research, I felt encouraged to take a closer look at the ways in which participants (teachers, researcher, etc) re-constituted and shaped their realities and identities throughout the inquiry. Most importantly, I came to realize the importance of problematizing those issues of objectivity, reliability and generalizability so commonly present in most quantitative--and some qualitative-studies, among other aspects.

Nevertheless, at the time I was in the search for local educational and ELT narrative-oriented studies, I noticed that although narrative research was widely implemented in international contexts, little had been done in the Colombian scenario or, at least, little had been made known to the academic community through specialized journals or events. Consequently, I decided to take this paper as an opportunity to illustrate some of the foundations and methodological considerations underlying narrative research, so that novice Colombian researchers willing to undertake a narrative research project could know more about this form of inquiry.

Although there is not a simple, clear definition of narrative (Riessman, 2008) and no single way of going about narrative research, there are certainly some concepts and characteristics that illustrate the grounds of this approach. In the subsequent sections of this paper, I will therefore address some of the events related to the origin of narrative research as well as some of the epistemological and methodological considerations that determine the role of the researcher, the different orientations narrative studies can take, and the processes involved in narrative analysis. Some of the challenges narrative researchers face in their work as well as the contributions that this method of inquiry has made to the educational and TESOL fields will also be considered.

\section{A Close-up Look at Narratives}

To trace the origin of narrative, often used synonymously with the word story, it is necessary to consider the beginning of humankind. Barthes (n.d., cited in Riessman, 2008) notes that narratives began with the history of mankind and that therefore "there nowhere is nor has been a people without narrative ... it is simply there, like life itself" (p.11). We are storytelling creatures who construct narratives to make sense of lived experiences and, ultimately, of our and others' passage through the world (Moen, 
2006). Through our narrative accounts, our past and present regain meaning: "The human being alone among the creatures of the earth is a story telling animal: sees the present rising out a past, heading into a future; perceives reality in narrative form" (Novak, 1975, cited in Craig, 2007, p.174). A story is thus "a portal through which a person enters the world and by which their experience of the world is interpreted and made personally meaningful" (Connelly and Clandinin, 2006, p. 375).

According to Polkinghorne (1995), narrative descriptions exhibit human activity as purposeful engagement in the world: "Narrative is the type of discourse that draws together diverse events, happenings and actions of human lives" (p.5). A story is a special type of discourse production; it is a sustained emplotted account with a beginning, middle, and end. As stated by Scholes, (1982, cited in Carter, 1993), in a story there are at least three basic elements: (a) a situation involving some conflict or struggle, (b) a protagonist who engages in the situation for a purpose, and (c) a sequence with implied causality (a plot) during which the conflict is resolved: "A narration is the symbolic presentation of a sequence of events connected by subject matter and related by time" (p.6).

In a story, as Pokinghorne claims, events and actions are put together into an organized whole by means of a plot. This process of emplotmment, where a prior action is causally linked to a later effect, is what actually distinguishes a story from a simple list of facts. Narratives thus give order to elements that would otherwise be random and disconnected. They provide connections, coherence, and sense; they give our experiences and understanding structure; they are our way "of being and dealing with time" (Carr, 1986, cited in Webster and Mertova, 2007, p.2).

Nonetheless, it is important to bear in mind that narratives are "not an objective reconstruction of life-- [they are] a rendition of how life is perceived" (Webster and Mertova, p.3); they are based on people's life experiences and entail chosen parts of their lives. Every time an account takes place, as contended by Riessmann (2008), speakers select and evaluate those events they perceive as important and connect them sequentially so as to allow listeners to take particular meaning away from their story. Stories thus reflect "the power of memory to remember, forget, neglect, and amplify moments in the stream of experience" (p.29).

Additionally, our stories are constantly being restructured in the light of new events and they "do not exist in a vacuum but are shaped by lifelong personal and community narratives" (Webster and Mertova, 2007, p. 2). According to Moen (2006), in agreement with Elbaz-Luwisch (2005), narratives are both personal and collective. They are shaped by the knowledge, experiences, and feelings of the narrator as well as by the interlocutors and the cultural, historical and institutional settings in which they occur. Stories not only highlight an existing relationship between the narrator and listener/ reader, but they also expose issues related to both identity and cultural membership.

As Riessman (2008) points out, we engage in a process of identity construction through storytelling; we construct who we are and how we "want to be known". Through the words and the narrative structures we use in the crafting of our stories and through the very content of these, we identify with other members of society and show our affiliation to a particular cultural group. In so doing, we also assign identities to others, "both to the characters who appear in [our] narratives and to [our] interlocutors" (Menard-Warmick, 2011, p.565).

All in all, our stories manifest our human nature; they mirror how we are socially and culturally positioned in the world (Sikes and Gale, 2006). They expose our identities, what we hold on to in order to read and act in the world. Yet, as stated by Pavlenko (2007), our stories do not completely belong to us:

...they are co-constructed for us and with us by our interlocutors, real or imagined, by the time and place in history in which the events portrayed have taken place and the time and place in which they are told, by the language we choose for the telling, and by the cultural conventions of the speech community in which the narrative is located. (p.180) 


\section{The Narrative Turn}

In the last decades, narratives and, in particular, stories people tell about their lives have become the focus of the evolving field of narrative research (Pavlenko , 2002; Craig, 2007; Riessman, 2008). There is an increasing interest in narratives in fields like psychology, sociology, education and in other areas in linguistics, like language teaching, L1 and L2 acquisition and sociolinguistics. According to Riessman and Speedy (2006), narrative has penetrated almost every discipline and school and it no longer refers exclusively to literary work. It is now interdisciplinary and therefore does not fit "within the boundaries of any single scholarly field" ( $p$. 426-427). As Pavlenko (2002) and others contend, narratives have become both the object and the form of narrative inquiry and a legitimate means of research for all areas of human science. But, how and why were narratives given entry to the field of social science research?

Although the idea that human beings are storytelling creatures is quite ancient, narratives were not seen as relevant to research until recently (Carter, 1993). In an attempt to define narrative, Currie (1998, cited in Sikes and Gale, 2006), suggested revising the term homo sapiens to homo fabulans to indicate that we are actually "tellers and interpreters of narrative" (para. 6). Throughout time, however, in our attempts to claim what is to be valued as "truth", our homo sapiens seems to have overshadowed our homo fabulans. In our task of objectively knowing the world, stories used to hold no relation with the discovery of the "truth", and they had, in some way, been marginalized. Additionally, as Polkinghorne (1995) notes, the word story had carried for some a connotation of falsehood or misrepresentation, as in the expression, "That is only a story" (p.7).

An impetus for change developed, however, as a result of various political, social and methodological happenings such as the interpretive shift in modern approaches to inquiry, the recognition that story embodies a way to understanding life or human actions (Carter, 1993), as well as the creation of women movements and a contemporary preoccupation with identity (Riessman, 2008). Pinnegar and Daynes (2006) note that the turn or turns to narrative research represent a change in: a) the relationship between the researcher and the researched, b) a move from the use of number toward the use of words as data, c) a change from a focus on the general and universal toward the local and specific, and d) an increasing acceptance of alternative epistemologies or ways of knowing. Narrative research therefore implies changes in the relationships among researcher and participants, the kind of data collected, the focus of the study, and the kinds of knowing embraced by the researcher. All in all, narrative research is a move away from positivism.

In this narrative turn, the work of Bruner and Polkinghorne is crucial. As Pinnegar and Daynes (2006) contend, Bruner's distinction between paradigmatic and narrative knowing articulate the historical basis for the credibility of narrative knowing, and in turn of narrative research. In paradigmatic knowing, individual things or actions are believed to belong to a concept or category, while in narrative knowing events are linked into a context-rich network. Paradigmatic knowing relies on the logic of rationality and makes use of formal abstractions, concepts, and constructs, which are independent of any particular context. Narrative reasoning, by contrast, emphasizes the temporal context and complex interaction of the elements that make each situation unique: "While paradigmatic knowledge is maintained in individual words that name a concept, narrative knowledge is maintained in emplotted stories" (Polkinghorne, 1995, p.11).

Polkinghorne (1995) builds on Bruner's distinction between paradigmatic and narrative reasoning to highlight the significance of narratives as well as to examine two ways to conduct narrative research. One that employs paradigmatic cognition, named analysis of narratives, and other that employs narrative cognition, defined as narrative analysis. In the first type, researchers collect stories as data (personal journals, autobiographies, oral statements, interviews, etc) and analyze them with paradigmatic processes. Paradigmatic analysis is employed to 
identify the concepts and categories that are present in the data as well as to the note relationships among categories.

In the second type, the researcher's task is "to configure the data elements (not usually in storied form and which could come from field work, participant observation,

personal and public documents and interviews) into a story that unites and gives meaning to the data as contributors to a goal or purpose" (p.15). The researcher must discover a plot that illustrates the connections among the data elements. Thus, analysis of narratives moves from stories to common elements, and narrative analysis moves from elements to stories. In both types of analyses the outcome is a story.

All in all, Bruner's and Polkhinghorne's work not only ratify the existence of more than one way of reasoning but also opens a door to an alternative method of inquiry that challenges the "singular mode advocated" by the (quantitative) research tradition. In the specific field of educational research, as Carter (1993) observes, stories became a way of capturing the complexity of the phenomenon with which educational researchers contend, and thus, "redressed the deficiencies of the traditional atomistic and positivistic approaches in which teaching was decomposed into discrete variables and indicators of effectiveness" (p.6).

In what follows, I attempt to address in more detail some of elements or aspects inherent to narrative research (mentioned by Pinnegar and Daynes, 2006) such as the relationship among researcher and participants, the focus of the study, and the knowing embraced by the researcher.

\section{The narrative researcher}

Narrative research, as illustrated above, is unconstrained by the characteristic objectivity of positivism and focuses instead on interpretation and the understanding of meaning. Narrative inquirers recognize that the researcher and the participants are "in relationship with each other and that both parties will learn and change in the encounter"
(Pinnegar and Daynes, 2006, p. 10). Who the researcher and the researched are will inevitably emerge in the interactions as they both bring their own experiences, histories and worldviews to the inquiry process. As previously stressed, narratives are not solely individual productions but they are shaped by social, cultural, and historical contexts as well as by the relationship between the narrator and the interlocutor (Pavlenko. 2007).

Narratives are naturally co-constructed: A narrative researcher "does not find narratives but instead participates in their creation" (Riessman, 2008, p.219). As Barkhuizen (2011) states, researchers are not passive listeners, but on the contrary, are part of the story that is being told or created, both as characters and as narrators. As characters, they become part of the narratives and shape to some extent their content and structure, and as narrators, they both interpret and "represent participants' accounts of lived and imagined personal experience" (p.393).

As Clandinin (2006) pinpoints, narrative researchers cannot step out of or remove themselves from the inquiry, but rather "need to find ways to inquire into participants' experiences, their own experiences as well as the co-constructed experiences developed through the relational inquiry process" (p.47). They too become part of the world they study. The fact that the inquiry is altering the phenomena under study is not regarded as a methodological problem to be overcome, but is the purpose of the research. As a result, there is an active process of negotiation where relationships and research purposes are collaboratively constructed.

To Carter (1993), one of the central problems in research on teachers' voices is a question of narrator distance from the main characters in the stories that are being told. In most conventional studies the researcher assumes a superior, more knowing attitude toward teachers: "It is the narrator who has access to the relevant literatures, who frames the study, who provides the interpretations, and who modulates the teachers' voice" (p.9). By contrast, in narrative studies a constant dialogue between researcher and teachers (or other school actors) is generated so that they can both, in light of their 
personal understandings of particular teaching and learning situations, collaboratively re-construct and make sense of what happens inside and outside the classroom. According to Cortazzi (1993), "in asking the participants to read, edit, and otherwise collaborate on the construction of their own personal teaching stories, a researcher seeks to make their lives present. And ultimately, it is this type of procedure and discourse between participants and researcher that is most vital for the narrative to succeed" (p.16).

\section{Focus on form, content and context}

As we have seen, narrative research motivates a change in the relationship among researcher and participants; however, it also implies changes in the focus of study and the type of data collected. Studies can investigate narratives as their research object, where the focus is on the narrative itself, or they can take narratives as a means for studying other questions (Lieblich, Tuval-Mashiach, and Zilber, 1998). In the former, researchers concentrate on the formal aspects of the narratives, such as the structure of story, the organization of content, or the use of language, while in the latter; they concentrate on the content of the narratives. These two perspectives have been distinguished by some as narrative study and narrative inquiry. As stated by Barkhuizen (2011), narrative research means different things to different researchers:

For some, it means becoming involved in the big stories of their participants' lives, opening up and exploring vast spatiotemporal landscapes. For others, it means focusing on the here and now of narrative small stories generated in talk-ininteraction. For some, reflections on the content of past experience are important [narrative inquiry], and for others, it is the form of emergent narratives in conversation [narrative study] that attracts analytical attention. (p.409)

Some of the narrative work conducted in the specific context of education has taken place within the framework of narrative inquiry. In this telling of big stories, the focus is on the content of the narratives; "what they are about; what was told; and why, when, where, and by whom" (Barkhuizen, 2011, p.401). Researchers, as Moen (2006) contends, use narrative as a way to represent a qualitative study (e.g. autobiographies and life histories), as a method of inquiry, and as a frame of reference in the research process. Connelly and Clandinin (2006), following Dewey's pragmatic philosophy, note that arguments for the development and use of narrative inquiry are inspired by a view of human experience in which humans, individually and socially, lead storied lives. Narrative researchers do not only focus on individuals' experience, but also explore "the social, cultural, and institutional narratives within which individuals' experiences were constituted, shaped, expressed, and enacted" (p.42).

In the TESOL field, researchers have also followed the narrative inquiry tradition and have explored language teaching and learning matters by attending to participants' past experience. $\mathrm{Ne}$ vertheless, recently, as Barkhuizen (2011) contends, attention has also been paid to the interactional contexts of narrative production and to the ways participants and researchers perform their identities as they narrate their stories. Some researchers therefore analyze mundane talk in conversations or interviews (referred to as small stories), rather than big narratives (like life histories) that are assembled not only from interviews but from other ethnographic data collected over an extended period of time.

In both the educational and TESOL field, narrative researchers make use of different methods and rely on different, though not necessarily competing, epistemological or theoretical ideas, which seems to confirm that narrative research is an approach having no particular rules of thumb to make sense of the phenomena under study. So, narrative research might be best considered, as Smith (2007, cited in Barkhuizen, 2011) notes, "an umbrella term for a mosaic of research efforts, with diverse theoretical musings, methods, empirical groundings, and/ or significance all revolving around an interest in narrative" (p. 392).

Analyzing content and form. Although there are no unique ways to go about narrative research, there are certainly some elements (content, form, and context) which seem to be present at the analysis 
stage of all narrative work, whether it is content or form-oriented. An analysis of content involves to some extent an analysis of form and vice versa. Content, context, and form are inextricably linked and, for some (Pavlenko, 2007), an understanding of content is not possible "without close analysis of both context and form" (p.174). Nevertheless, it is important to bear in mind that the type of analysis a narrative researcher engages in is linked to the type of information gathered.

This information, as Pavlenko observes, might be related to subject reality (how things/events were experienced by participants), life reality (how things are or were), and text reality (ways in which things were narrated). According to Pavlenko, studies of autobiographic narratives commonly focus on one of the three types of information, those that examine subject reality being the first and largest group. This first group of studies involves a thematic or content analysis where the main analytical step is the coding of narratives according to emerging themes, patterns, and categories. The second group focuses on life reality and in this case narratives are treated as facts rather than as discursive constructions; "this treatment disregards the interpretive nature of storytelling, that is the fact that the act of narration unalterably transforms its subject and any further interpretation interprets the telling and not the event in question" (p.170). The third group is concerned with text reality instead. These studies look at the interactional contexts of the narratives (Barkhuizen 2011), and they specifically examine how linguistic features and narrative structures are used by the narrators to attain certain narrative functions.

Analyzing context. Context is relevant to narrative research. It is at the heart of narrative researchers' work as it helps both the narrator and the researcher make meaning of their stories. Context, however, as Barkhuizen (2011) notes, can also be interpreted on a number of levels. It can be examined at the micro level of interaction, at the level of the narrative telling, and at the sociocultural macro level underlying narrative construction. In the first level, sequences of turns and the role of the speakers in the conversation are analyzed in detail. In the second, issues such as the time of day, physical setting, language choice, purpose of talk, are considered. The third, broader level relates to multiple contexts beyond the context of the conversation and, as Clandinin and Rosiek (2006) claims, beyond the researcher's control-in that spatial contexts, cultural contexts, social contexts, institutional contexts, place contexts, and people contexts are all present- (p.45).

As a result of the myriad of elements present in narratives, researchers are therefore encouraged to consider not only what was said (subject reality), but also how it was said and why (text reality). Pavlenko (2007) also suggests attending to both global and local contextual influences affecting narrative constructions; that is to say, the historic, political, economic, and cultural circumstances as well as to "the influence of language choice, audience, setting, modality, narrative functions, interactional concerns, and power relations on ways in which speakers and writers verbalize their experiences" ( $\mathrm{p}$. 175). Attending to all these intertwined aspects not only gives the narrative researcher a richer view of the phenomena under study but also enhances the quality of the analysis.

Nevertheless, despite the suggestion to attend to content, form and context in all their interrelatedness and complexity; the analysis of data in narrative research is, as previously mentioned, definitely shaped by the focus of the study and the theoretical, epistemological and methodological views guiding the research and researcher. Therefore, the meanings attached to content, context and form and the ways in which these aspects are analyzed vary from study to study. While an emphasis on the content of narratives might lead to an exploration of context at the second and third level, an emphasis on form might lead to an analysis of the micro context that is built in interaction instead.

It is also important to note that the process of meaning making that narrative researchers go through is not only concerned with the stage of data analysis, but it in fact takes place all along the inquiry. Narrative research is an ongoing interpretive process. The interpretation starts immediately when one story is selected out of any number of 
other possible stories and it continues during the entire research process, even after the research report is finished (Moen, 2006, p7). Meaning making takes place when stories are told, when researchers analyze their data and discuss their interpretations with participants, and when stories are retold (in research texts) and interpreted by others. Narrators, researchers, and readers engage in meaning making at various stages of the research process (Barkhuizen, 2011).

Barkhuizen refers to this multistage, active meaning making as narrative knowledging: "Narrative knowledging, ... is the meaning making, learning, or knowledge construction that takes place during the narrative research activities of (co)constructing narratives, analyzing narratives, reporting the findings, and reading/watching/listening to research reports" (p.395). Every time participants retell their stories, researchers revisit their data, and readers interact with finished research texts, new or different understandings of experience emerge. Narratives are always open for (re) interpretation, for further narrative knowledging.

The recognition of a dynamic meaning-making process, together with all aforementioned characteristics, makes narrative research a relational mode of inquiry rooted in human action; yet, what makes it a legitimate approach to research also poses significant questions for researchers. Next, I will discuss some of the dilemmas present in narrative research as well as the contributions that this approach offers to both the educational and TESOL fields.

\section{Dilemmas and Challenges}

In the literature on narrative research there are various discussions around the dilemmas or issues narrative inquiries face at different stages of their work. Some of the most recurring themes are the role of interpretation and the question of truth. Narratives, as Barkhuizen (2011) stresses, undergo multiple layers of interpretation by the time they are constructed as data; "what we hear in an interview or read in a teacher journal has imposed structures on and re-shaped the actual life events" (p.406); life events are filtered through the meaning making processes the participants and the researcher go through. This phenomenon, as Barkhuizen and Bakhtin (1986) contend, naturally raises the question of whether the stories we are told are true.

Addressing this question, Moen (2006) reminds us of one of the claims inherent in narrative research: the existence and presence of different subjective positions from which we experience and interpret the world, and therefore, the absence of a static and everlasting truth. As argued by Cadman and Brown (2011), truth is always partial, constructed, contextual, contingent, possibly conflictual, morphing, and ever unfinished (p. 451). Consequently, establishing a difference between a life as lived, experienced, and told is crucial for narrative researchers, a distinction that has been made by Bruner and other researchers like Polkinghorne (2007) and Pavlenko (2007). In Bruner's terms, a life lived is what actually has happened. A life experienced consists of the images, feelings, sentiments, desires, thoughts, and meanings known to the person whose life it is. And, a life told is a narrative or several narratives influenced by the cultural conventions of telling, by the audience, and by the social context (Bruner, 1984).

In life as told, both the narrator and the interlocutor inevitably step away from the real-life event or events that prompted the story in question (Moen, 2006). Hence, as stated by Bell (2002), whether or not people believe the stories they tell is relatively unimportant as the inquiry goes beyond the specific stories to examine the assumptions inherent in their shaping: "No matter how fictionalized, all stories rest on and illustrate the story structures a person holds. As such they provide a window into people's beliefs and experiences" (p.210). Narrative research therefore presents stories about remembered events and how these were interpreted rather than how they actually happened.

In addition to the question of truth, there is another issue facing narrative inquirers: the risk of legitimizing the values of a particular culture. In emphasizing narrative, as Schiff (2006) and Sartwell (2006) observe, researchers may be "reifying a Western, arguably middle and upper class, concept as the universal mode of shaping and articulating 
subjective experience", as well as neglecting other ways "of organizing experience or the importance at times of leaving experience unorganized" ( as cited in Barkhuizen, 2011, p.395). Narrative inquirers may neglect that people may structure and tell their stories in ways that are quite different from the Western narratives: "A story elicited in one language may be shaped by conventions of another and thus may not be heard as such or may be misunderstood" (Pavlenko, 2002, p 214).

In this regard, Riessman (1991) and Pavelnko (2002) suggest attending to differences in narrative conventions so as to avoid the silencing of nonconforming voices as well as the privileging of some participants' stories over those of others. Carter (1993) also cautions researchers to sanctify storytelling work to the point that they "simply substitute one paradigmatic domination for another without challenging domination itself" (p11). Narrative researchers must therefore be aware of issues involved in story, such as authenticity, interpretation, and normative value so to make sure their work is both credible and morally responsible.

Nonetheless, despite the inherent risks or dilemmas narrative research might pose, it has contributed to the educational and TESOL field in various ways. As stated by Cadman and Brown (2011), "in participants' narratives we can begin to hear their voices, hear how they construct themselves discursively, in imaginative interpretation of the lives they want to tell" (p. 451).

\section{Why Narrative Research?}

Narrative research has contributed in different ways to the educational and TESOL fields. Both of these fields, though exploring diverse educational matters, have mostly focused on teacher education and school change by looking at the ways in which teachers' narratives shape and inform their practice (Bell, 2002). This has been so, as the stories that we read and hear in and outside the classroom help us learn not only about the subject matter of instruction or about the strengths and shortcomings of teaching itself (Webster and Mertova, 2007, p.15), but also about the ways in which teachers come to make sense of the world that surrounds them. As Elbaz (1991) explains:

Story is the very stuff of teaching, the landscape within which we live as teachers and researchers, and within which the work of teachers can be seen as making sense. This is not merely a claim about the aesthetic or emotional sense of fit of the notion of story with our intuitive understanding of teaching, but an epistemological claim that teachers' knowledge in its own terms is ordered by story and can best be understood in this way. (p. 3)

According to Craig (2011), teacher knowledge in narrative research has a narrative history, is growthoriented and continuous, and necessarily involves relationships among people: "Sitting at the root of the teacher knowledge conception of teacher education as studied through the narrative inquiry lens is a different understanding of expertise" (p.2). As stated by Clandinin (2006), narrative provides the possibility to understand how the personal and social are intertwined in teachers' lives and how these experiences are shaped by the larger social, cultural and institutional narratives in which teachers have lived; home and school places that shape largely the nature of the stories they live and tell.

When researchers divide the reality of the classroom into elements, as Moen (2006) pinpoints, there is a risk of losing sight of the whole. In narratives, however, the complexity of the classroom is not broken down and the multivoicedness of teaching is captured: "In this way, narratives bring practice up close (Carter, 1993), contributing, we hope, to provoking, inspiring, and initiating discussions and dialogues, something that is crucial for reflection on practice and its development" (Moen, 2006, p.9). These discussions, as Moen observes, give teachers the possibility of making their voices heard; voices, that contrary to those of politicians, researchers, and administrators, seem to absent from the public debate on teaching.

According to Clandinin (1986), the lack of success of curriculum implementation reported in the literature is linked to a view which minimizes the teacher as an active, autonomous agent and a user of practical knowledge. This practical knowledge not 
only refers to what teachers know about the instructional content they teach, but also to the knowledge they hold about themselves, their students and their school context. Thus, when a narrative view of teacher is adopted, the importance of coming to understand teachers' practical knowledge is valued as well.

Likewise, as Barkhuizen (2008) observes, there are various reasons why narrative inquiry is valuable for teachers. By sharing their stories, teachers have the opportunity to reflect on their own practice, to obtain an understanding of their own knowledge and actions and, therefore, to act accordingly by making any necessary changes. Reflecting on their stories allows them to see the whole picture, what is behind their and others educational doings. Narrative research thus offers researchers the opportunity to present the complexity of teaching and learning to teachers themselves and to the public. It is this fundamental link of narrative with teaching and learning as human activities which directly confirms its value as an educational research tool (Webster and Mertova, 2007).

Narratives also allow for learners' voices to be heard on a par with those of teachers and researchers. Researchers can "gain insights into learners' motivations, investments, struggles, losses and gains as well as into the ... ideologies that guide their learning trajectories" (Pavlenko, 2002, p.214). They can also examine whose stories are being heard, whose stories are being misinterpreted, and why. According to Pavlenko, by analyzing the rhetorical influences that shape narrative constructions, that is by attending to the structural aspects of narrative, we will be able to better understand how stories are being told and why they are being told in a certain way. Narrative research offers practitioners and researchers the possibility to make sense of educational experience in an alternative way. As contended by Carter (1983), it brings practice "up close" rather than "out there", which is why, among many other reasons (described above), this paper is an invitation to explore such an approach to research.

\section{Research on teaching and learning}

During the last decades, researchers have studied teachers' and students' experience of curriculum in multiple ways and have highlighted different phenomena. Themes and concepts such as teachers' images and personal practical knowledge (Clandinin,1986), pedagogical content knowledge (Gudmundsdottir, 1991), teacher as curriculum maker (Clandinin and Connelly, 1992), professional knowledge landscapes (Clandinin and Connelly, 1995), narrative authority (Olson,1995), narrative communities of knowledge (Craig, 2001), curriculum as a multistoried process (Olson, 2000), and multivoicedness (Elbaz-Luwisch, Moen and, Gudmundsdottir, 2002) have emerged with the objective of providing interpretations for and calling attention to issues of identity, agency, diversity, and multiculturalism, aspects which have undoubtedly exposed an alternative understanding of curriculum making and school change.

In the TESOL field, matters linked to identity formation (Simon-Maeda, 2004; Tsui, 2007; Liu \& $\mathrm{Xu}, 2011$ ), teachers' pedagogical beliefs (Barnard \& Nguyen, 2010), teachers' professional development (Golombek \& Johnson, 2004), language learning narratives (Pavlenko, 2002), and tensions between mandated curriculum and personal theories of best practice (Wette \& Barkhuizen, 2009) have also been explored.

\section{Concluding Thoughts}

In order to truly understand teaching and schools, as Elbaz-Luwisch (2007) maintains, it is required that we listen to teachers' voices and the stories they tell about their work and lives: "Narrative research on teaching ... develop[s] out of teachers' stories about their work and their dialogues with one another, with pupils, with teaching materials, and with themselves" (p.358). It recognizes the fact that teachers' disciplinary knowledge and what is taught or given to them (as prescribed curricular programs) are subsumed under their tacit knowledge; the background knowledge they carry in their minds and bodies and which governs how they approach the 
practical world (Xu \& Conelly, 2009). It is through this personal knowledge that teachers make sense of their professional experience.

Narrative research, however, not only involves the individual and idiosyncratic, it also refers to the context, to the "embeddedness of the teacher in a school and school system and its mandated curricula, ideologies, pedagogical trends, and reform processes" (Clandinin and Connelly, 2000, p.359). Consequently, examining educational practices narratively is to view teaching as expressions of embodied personal and social stories, and to think of teachers as individuals who ought to be understood as such, but who are also always part of a social context.

According to Elbaz-Luwisch (2007), this view on teaching calls attention to the wider social, cultural, political, and historical contexts of this profession and reminds us that it is an activity shaped by the various discourses at work in society in a given period, as well as a moral practice "concerned with the realization of values and ends-in-view of the teacher for the benefit of students" (p.367). Xu \& Connelly (2009) see in narrative inquiry an opportunity to understand how teachers relate to external forces like policy and curriculum materials as they teach. For them "learning how teachers experience and narrate the teaching act, and the reform intentions they are expected to teach, says much about education as a form of living" (p.221). A narrative understanding of teaching and curriculum thus opens new discussions as to the ways innovations and reforms are planned, implemented and studied.

Additionally, by attending to teachers' personal practical knowledge and by helping them identify the personal stories they live by as well as those stories that have been written for them (Pavlenko, 2002), they might be able to notice how they are being positioned as (language) professionals, which might result in the construction of new stories for students and communities. As Clandinin (2006) states:
Perhaps in listening and attending to teachers' stories ... we can create conditions that allow us to give them back their stories and perhaps help them see the social, cultural, and institutional stories they work within and that shape them. As [teachers] begin to awaken to other stories of community, we might see [them] begin to re-story [their] stories to live by. Perhaps we can begin to work together to change those social, cultural and institutional narratives. (p.52)

In this paper, I have discussed what underlies the narrative turn as well as what narrative research implies in terms of the relationships established among researcher and participants, the kinds of data gathered, and the process of data analysis. I have also described some of the dilemmas narrative researchers must face as well as the contributions this approach has propagated in the educational and TESOL fields. By knowing more about the world of narrative research, more research experiences could eventually take place in the Colombian ELT field, and as a result, alternative representations of the stories that our students, teachers, administrators, and communities live by as they participate in language learning programs might also be created.

\section{References}

Bakhtin, M. (1986). Speech genres \& other late essays (C. Emerson \& M. Holquist (Eds.). Austin: University of Texas Press.

Barkhuizen, G. (2008). A narrative approach to exploring context in language teaching. English Language Teaching Journal, 62(3), 231-239.

Barkhuizen, G. (2011). Narrative Knowledging in TESOL. TESOL Quarterly, 45(3), 391-414. doi: DOI 10.5054/ tq.2011.261888.

Barnard, R., \& Nguyen, G. V. (2010). Task-based language teaching (TBLT): A Vietnamese case study using narrative frames to elicit teacher's beliefs. Language Education in Asia, 1, 77-86.

Bell, J. S. (2002). Narrative inquiry: More than just telling stories. TESOL Quarterly, 36(2). 207-213, doi: $10.2307 / 3588331$. 
Bruner, E. M. (1984). Introduction: The opening up of anthropology. In S. Plattner \& E. M. Bruner (Eds.), Text, play, and story: The construction and reconstruction of self and society-1983 proceedings of the American ethnological society (pp. 1-16).Princeton, NJ: American Ethnological Society.

Cadman, C., \& Brown, J. (2011). TESOL and TESD in remote aboriginal Australia: The "true" story? TESOL Quarterly, 45(3), 440-462.

Carter, K. (1993). The place of story in the study of teaching and teacher education. Educational Researcher, 2(1), 5-12.

Clandinin, D.J. (1986). Classroom practice: Teacher images in action. Philadelphia: The Falmer Press.

Clandinin, D.J. (2006). Narrative inquiry: A methodology for studying lived experience. Research Studies in Music Education, 27, 44-54.

Clandinin, D.J., \& Connelly, F.M. (1992). The teacher as curriculum maker. In P.W. Jackson (Ed.), Handbook of research on curriculum: A project of the American Educational Research Association (pp. 363-401). New York: Macmillan.

Clandinin, D.J., \& Connelly, F.M. (2000). Narrative inquiry: Experience and story in qualitative research. San Francisco: Jossey-Bass Publishers.

Clandinin, D. J., \& Rosiek, J. (2006). Mapping a landscape of narrative inquiry: Borderland spaces and tensions. In D. J. Clandinin (Ed.), Handbook of narrative inquiry: Mapping a methodology (pp. 35-75). Thousand Oaks, CA: Sage.

Connelly, F. M., \& Clandinin, D. J. (1995). Teachers' professional knowledge landscapes: Teacher stories. Stories of teachers. School stories. Stories of school. Educational Researcher, 25 (3), 24-30.

Connelly, F. M., \& Clandinin, D. J. (2006). Narrative inquiry. In J. L. Green, G. Camilli, P.Elmore (Eds.), Handbook of complementary methods in education research (3rd ed.,pp. 477 - 487). Mahwah, NJ: Lawrence Erlbaum.

Cortazzi, M. (1993). Narrative and the study of teaching: Narrative analysis. London: Routledge.

Craig, C. J. (2001). The relationships between and among teachers' narrative knowledge, communities of knowing and school reform: A case of "the monkey's paw”. Curriculum Inquiry, 31(3), 303-331.

Craig, C.J. (2011). Narrative inquiry in teaching and teaching education. In Kitchen, J., Parker, D. C., \&
Pushor, D. (Eds.), Narrative Inquiries Into Curriculum-making in Teacher Education (pp. 19-42). Emerald Book Serials and Monographs.

Elbaz, F. (1991). Research on teachers' knowledge: The evolution of a discourse. Journal of Curriculum Studies, 23, 1-19.

Elbaz-Luwisch, F. (2007). Studying teachers' lives and experiences: Narrative inquiry into $\mathrm{K}-12$ teaching. In D. J. Clandinin (Ed.), Handbook of narrative inquiry: Mapping a methodology (pp. 357-382). Thousand Oaks, CA: Sage.

Elbaz-Luwisch, F., Moen, T., \& Gudmundsdottir, S. (2002). The multivoicedness of classrooms: Bakhtin and narratives of teaching. In H. Heikkinen, R. Huttunen, \& L. Syrjälä (Eds.), Biographical research and narrativity (pp. 197-218). Jyväskylä, Finland: SoPhi Press.

Golombek, P. R., \& Johnson, K. E. (2004). Narrative inquiry as a mediational space: Examining emotional and cognitive dissonance in second-language teachers' development. Teachers and Teaching: Theory and Practice, 10(3). 307-327.doi:10.1080/13540600 42000204388.

Gudmundsdottir, S. (1991). Story-maker, story-teller: Narrative structures in curriculum. Journal of $\mathrm{Cu}$ rriculum Studies, 23(3), 207-218.

Lieblich, A., Tuval-Mashiach, R., \& Zilber, T. (1998). Narrative research: Reading, analysis and interpretation. Newbury Park, CA: Sage.

Liu, Y., \& Xu, Y. (2011). Inclusion or exclusion? A narrative inquiry of a language teacher's identity experience in the 'new work order' of competing pedagogies. Teaching and Teacher Education, 27(3), 589-597. doi:10.1016/j.tate.2010.10.013.

Menard-Warwick, J. (2007). "Because she made the beds. Every day." Social

positioning, classroom discourse, and language learning. Applied Linguistics, 29(2), 267-289. doi:10.1093/ applin/amm053.

Mendieta, J. (2011). Teachers' knowledge of second language and curriculum: A narrative experience. PROFILE 13(1), 89-110.

Moen, T. (2006). Reflections on the narrative research approach. International

Journal of Qualitative Methodology, 5(4), 1-11. Retrieved, Jan 2012 from http://www.ualberta.ca/ iiqm/backissues/5_4/pdf/moen.pdf 
Olson, M. (1995). Conceptualizing narrative authority: Implications for teacher education. Teaching and Teacher Education, 17(6),119-135.

Olson, M. (2000). Curriculum as a multistoried process. Canadian Journal of Education, 25(2),169.

Pavlenko, A. (2002). Narrative study: Whose story is it, anyway? TESOL Quarterly, 36(2), 213-218. doi: $10.2307 / 3588332$.

Pavlenko, A. (2007). Autobiographic narratives as data in applied linguistics. Applied Linguistics, 28(2), 163-188. doi:10.1093/applin/amm008.

Pinnegar, S., \& Daynes, J. G. (2006). Locating narrative inquiry historically: Thematics in the Turn to Narrative. In D. J. Clandinin (Ed.), Handbook of narrative inquiry: Mapping a methodology (pp. 3-34). Thousand Oaks, CA: Sage.

Polkinghorne, D. E. (1995). Narrative configuration in qualitative analysis. In J. A.

H. A. R. Wisniewski (Ed.), Life history and narrative (pp. 5-24). London: Falmer Press.

Polkinghorne, D. E. (2007). Validity issues in narrative research. Qualitative Inquiry,13(4), 471-486. doi:10.1177/1077800406297670.

Riessman, C. (1991). When gender is not enough: Women interviewing women. In J. Lorber \& S. Farrell (Eds.), The social construction of gender (pp. 217-236). Newbury Park, CA: Sage.

Riessman, C. K., \& Speedy, J. (2006). Narrrative Inquiry in social work, counselling, and psychotherapy: A critical review. In D.J. Clandinin (Ed.), Handbook of narrative inquiry: Mapping a methodology (pp. 426456). Thousand Oaks, CA: Sage.

Riessman, C. K. (2008). Narrative methods for the human sciences. Los Angeles, Calif.: Sage Publications.

Sikes, P., \& Gale, K. (2006). Narrative approaches to educational research: Research in education. Retrieved, Dec 2008 from http://www.edu.plymouth.ac.uk/resined/ narrative/narrativehome.htm

Simon-Maeda, A. (2004). The complex construction of professional identities: Female EFL educators in Japan speak out. TESOL Quarterly, 38(3), 405-436. doi: $10.2307 / 3588347$.

Tsui, A. (2007). Complexities of identity formation: A narrative inquiry of an EFL teacher. TESOL Quarterly, 41(4), 657-680.
Xu, S., \& Connelly, F.M. (2009). Narrative inquiry for teacher education and development: Focus on English as a foreign language in China. Teaching and Teacher Education, 25(2), 219-227. doi:10.1016/j. tate.2008.10.006

Webster, L., \& Mertova, P. (2007). Using narrative inquiry as a research method: an introduction to using critical event narrative analysis in research on learning and teaching. London; New York: Routledge.

Wette, R., \& Barkhuizen, G. (2009). Teaching the book and educating the person: Challenges for university English language teachers in China. Asia Pacific Journal of Education, 29(2), 195-212. doi:10.1080/02188790902857180. 